\title{
Sehat Berinternet untuk Siswa Sekolah Dasar Selama Masa Pandemi di SD IT Ulul Albab
}

\author{
Ria Rismayati ${ }^{1}$, Ismarmiaty ${ }^{2}$ \\ riris@universitasbumigora.ac.id ${ }^{1}$, \\ ismarmiaty@universitasbumigora.ac.id ${ }^{2}$ \\ ${ }^{1,2}$ Universitas Bumigora
}

\begin{abstract}
Article History:
Received: 30-04-2021

Revised: 03-05-2021

Accepted: 12-07-2021
\end{abstract}

Keywords: Internet, Pandemic, SD IT Ulul Albab, Healthy Internet.

\begin{abstract}
This activity aims to provide knowledge related to the use of technology and other supporting devices that are good and safe for ustadz and ustadzah as a provision for the teaching and learning process at SDIT Ulul Albab. The pandemic caused by Corona Virus 2019 (COVID-19) has changed the process of human activities in almost the entire world. Socialization and face-to-face activities, especially learning carried out by teachers and students, have turned into face-to-face online networks, causing many new problems including difficulties in tutoring and filtering information in learning. Activities consist of stages of planning, preparation, implementation, evaluation and reporting. The results obtained were that of the total number of participants 28 people who were teachers at SDIT Ulul ALbab stated that they strongly agreed (82\%) that the activity material was new, followed by the evaluation results that participants felt that this activity was useful (71\%) and also teachers or ustadz / ustadzah at SDIT Ulul Albab feel that the activities carried out add insights related to healthy internet (96\%). Another result is an evaluation of the importance of tutors / teachers in gaining understanding and training related to a healthy internet, with $100 \%$ response "strongly agree".
\end{abstract}

\section{Pendahuluan}

Internet merupakan salah satu media komunikasi global yang pada saat ini dapat diakses hampir diseluruh lapisan masyarakat. Teknologi informasi ini telah berhasil mengubah beberapa cara seseorang maupun organisasi dalam menjalankan aktivitas sehari-harinya (Winarso et al., 2017). Mudahnya seseorang mengakses internet bisa berdampak negatif dan bisa pula berdampak sebaliknya, namun hal tersebut bukanlah menjadi suatu hambatan masyarakat untuk maju dalam mengikuti perkembangan teknologi informasi (Fitri, Rubiani, Astuti, \& Tasikmalaya, n.d.). (Adnjani, M.D., \& Madrah, 2014) dalam (Madrah, Muflihin, Ardi, \& Makhshun, 2019) menjelaskan bahwa anak-anak dan remaja adalah kelompok yang rentan terhadap paparan negatif budaya siber, dimana anak-anak dan remaja berada pada tahap masa pencarian identitas dan ingin mengeksplorasi diri 
secara bebas melalui internet. Dengan adanya rasa keingintahuan yang tinggi dengan didukung dengan fasilitas teknologi termasuk internet yang mudah dijangkau pada masa ini memberikan kenyamanan serta kekhawatiran terhadap informasi-informasi yang dapat menjadi manfaat serta juga dapat menjadi ancaman bagi pengguna termasuk anak-anak bersekolah. Pandemi yang disebabkan Corona Virus 2019 (COVID-19) telah mengubah proses kegiatan manusia di hampir seluruh dunia. Kegiatan sosialisasi dan tatap muka khususnya pembelajaran yang dilaksanakan oleh guru dan siswa telah berubah menjadi tatap muka online dalam jaringan (daring) sehingga menyebabkan banyak masalah baru termasuk kesulitan pembimbingan pembelajaran dan penyaringan informasi dalam pembelajaran.

Sekolah Dasar Islam Terpadu (SDIT) Ulul Albab merupakan salah satu sekolah di kecamatan Sandubaya kota Mataram yang terdampak dan harus melaksanakan pembelajaran secara daring. Pelaksanaan pembelajaran dilaksanakan dengan menggunakan teknologi messenger dan juga teknologi e-learning yang diharapkan dapat memaksimalkan penyampaian materi dan evaluasi pembelajaran dalam keterbatasan waktu. Selain itu, pembelajaran tetap dibagi dalam luar jaringan (luring) atau tatap muka langsung dengan melakukan kunjungan terjadwal pada masing-masing anak didik atau siswa dengan tetap memperhatikan protokol kesehatan untuk menegah terjadinya kemungkinan penularan terhadap virus COVID-19.

Melihat bahwa anak-anak merupakan bagian dari khalayak media massa yang termasuk dalam era internet, dimana saat ini anak-anak tumbuh dengan kemudahan akses baik dari rumah, sekolah maupun warnet (warung internet). Sehingga memungkinkan anakanak lebih mudah menggunakan internet dibandingakan orang tua mereka (Hanifah, 2011). Ustadz/ustadzah selain berperan sebagai pendidik juga sebagai fasilitator untuk mengarahkan siswa dalam penggunaan internet yang sehat. Hal tersebut menuntut guru untuk memiliki pengetahuan dan kemampuan teknologi khususnya terkait dengan internet sehat. Sehingga guru diharapkan mampu menjadi tongkat estafet dalam membantu mengarahkan siswa-siswinya untuk dapat menggunakan internet dengan baik dan sehat (Winarso et al., 2017). Menghindari penggunaan internet yang tidak terkontrol, berlebihan dan tidak benar menjadi latar belakang dilakukannya pengabdian di SD IT Ulul Albab oleh penulis dengan menargetkan para Ustadz/ustadzah atau guru mengenai sehat berinternet dalam sebuah kegiatan sosialisasi dan pembelajaran. Kegiatan ini bertujuan memberikan pengetahuan terkait penggunaan perangkat teknologi dan pendukung lainnya yang baik dan aman untuk ustadz dan ustadzah sebagai bekal pada proses belajar mengajar di SDIT Ulul 
Albab.

\section{Metode}

Pelaksanaan kegiatan pengabdian sesuai gambar 1 dapat dijelaskan dalam langkahlangkah tahapan antara lain:

1. Perencanaan : tahapan ini ketua dan anggota pelaksana melakukan inisialisasi terkait dengan pelaksanaan kegiatan pengabdian yang ingin dilakukan. Tema, bentuk kegiatan dan judul kegiatan serta konsep pelaksanaan acara dibahas pada tahapan ini. Selain itu, di tahapan ini juga dilakukan penentuan objek pelaksanaan kegiatan.

2. Persiapan : kegiatan persiapan dilakukan dengan melakukan koordinasi kepada objek yang telah ditentukan pada perencanaan kegiatan dan juga persiapan terkait pelaksanaan yaitu persiapan dokumen serta materi yang akan disampaikan pada saat pelaksanaan kegiatan.

3. Implementasi : kegiatan implementasi kegiatan pengabdian dilaksanakan dengan pelaksanaan kegiatan sosialisasi terkait dengan internet sehat. Pelaksanaan kegiatan dilakukan dalam 3 (tiga) hari pada tanggal 25, 26 dan 27 Maret 2021. Pelaksanaan dilakukan di aula pertemuan guru di SD Ulul Albab.

4. Evaluasi : evaluasi dilakukan dengan memberikan kuesioner terkait dengan pelaksanaan kegiatan pengabdian yang telah dilaksanakan. Daftar pertanyaan pada evaluasi adalah sebagai berikut:

$>$ Apakah materi kegiatan ini merupakan hal baru bagi anda?

$>$ Apakah acara ini bermanfaat bagi anda?

> Apakah acara ini menambah wawasan anda terkait internet-sehat?

> Apakah anda setuju bahwa pamong didik/guru/ ustadz-ustadzah penting diberikan pemahaman dan pelatihan terkait dengan internet sehat?

$>$ Menurut anda apakah anda setuju bahwa anak didik penting diberikan pemahaman terkait internet sehat?

Hasil dari evaluasi akan memberikan kesimpulan terkait pelaksanaan kegiatan.

5. Pelaporan.

Pelaporan kegiatan dilakukan untuk menghasilkan dokumentasi resmi dan publikasi dari kegiatan yang telah dilakukan.

Tahapan-tahapan pada kegiatan pengabdian dapat dilihat pada gambar 1 . 


\section{Perencanaan}

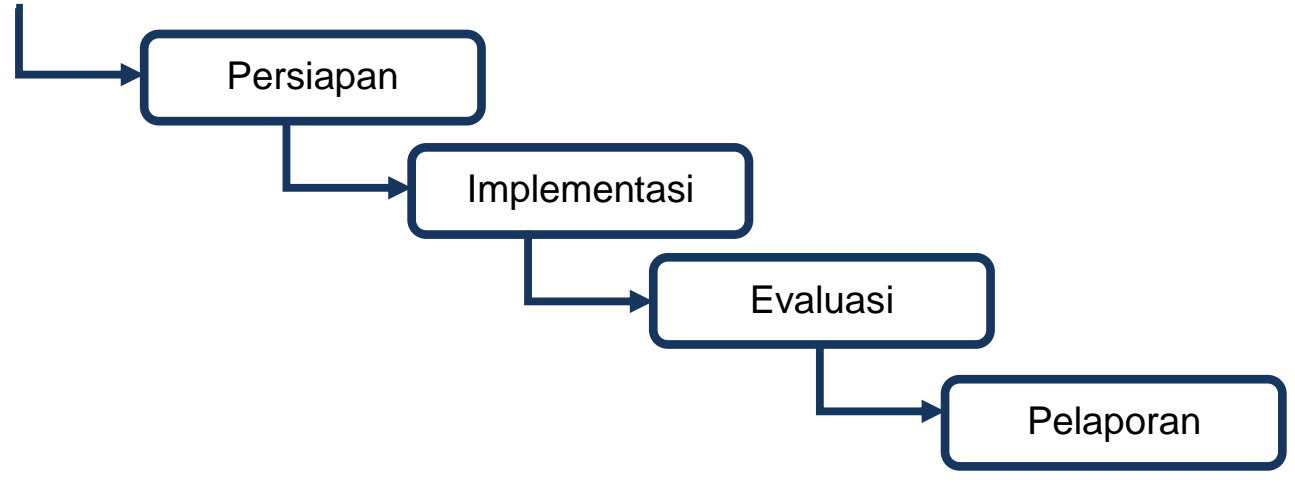

Gambar 1. Metode pengabdian

Pengabdian yang dilaksanakan pada SD IT Ulul Albab dimulai dengan melihat dampak dari pandemi yang mengharuskan siswa siswi maupun ustadz dan ustadzah melaksanakan kegiatan pembelajaran secara online. Dampak yang dihasilkan dari interaksi secara maya tersebut memungkinkan siswa, siswi, ustadz dan ustadzah menggunakan perangkat komputer dan internet melebihi pada kondisi normal pada umumnya. Hal tersebut dijadikan sebagai perencanaan awal untuk membuat kegiatan pengabdian kepada masyarakat terkait "Sehat Berinternet".

\section{Pembahasan}

Peserta kegiatan adalah guru atau yang disebut dengan ustadz dan ustadzah di Sekolah Dasar (SD) Islam Terpadu (IT) Ulul Albab. Ustadz dan ustadzah yang mengajar dari kelas 1 sampai dengan kelas 6 diwajibkan untuk melaksanakan kegiatan terkait internet sehat. SDIT Ulul Albab pada saat ini melaksanakan pembelajaran dengan mengkolaborasikan kegiatan tatap muka dengan kegiatan online class dengan menggunakan beberapa teknologi termasuk whatsapp messenger dan google classroom. Penggunaan beberapa aplikasi tersebut memberikan kemudahan pembelajaran dalam masa pandemi yang mengharuskan dilakukannya social distancing (pembatasan jarak) bagi kegiatan sosial. Kegiatan pembelajaran yang dilaksanakan dengan aplikasi dibekali dengan pengetahuan dan kemampuan untuk mengimplementasikan sehat berinternet bagi siswa. Pelaksanaan kegiatan belajar mengajar pada saat ini dilakukan dengan melaksanakan kegiatan tatap muka 3 (tiga) kali dalam 3 (tiga) hari pertemuan dan 3 (tiga) kali pertemuan secara online dalam 3 (tiga) hari. Pelaksanaan kegiatan tersebut dilakukan untuk mencukupi kebutuhan pertemuan dan target pembelajaran yang telah disusun dalam kurikulum. 
SDIT ULUL ALBAB

SEHAT

BERINTERNET

Kegiatan ini bertujuan memberikan

pengetahuan terkait penggunaan perangkat

teknologi dan pendukung lainnya yang baik dan

aman untuk ustadz dan ustadzah sebagai bekal

pada proses belajar mengajar di SDIT Ulul

Albab.
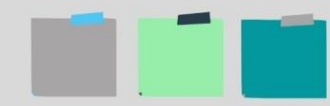

Gambar 2. Tampilan materi kegiatan sosialisasi sehat berinternet

Pelaksanaan tahapan perencanaan telah dilakukan oleh tim pengabdian di Universitas Bumigora terkait lokasi, rencana dan teknis pelaksanaan. Tahapan selanjutnya adalah persiapan materi terkait dengan Sehat Berinternet. Materi dipersiapkan oleh tim dengan mengadakan diskusi dan evaluasi terkait materi yang sesuai dengan latar belakang pendidik/ ustadz dan ustadzah yang mengajar di SDIT Ulul Albab. Tampilan isian materi dapat dilihat dari gambar 2 .

Tahapan selanjutnya yaitu implementasi pelaksanaan kegiatan sosialisasi sehat berinternet yang disampaikan di aula guru SDIT Ulul Albab. Pelaksanaan dilaksanakan dalam jangka waktu 3 (tiga) hari dengan rundown acara sebagaimana pada tabel 1.

Tabel 1. Rundown acara

\begin{tabular}{l|l}
\hline Waktu Pelaksanaan & \multicolumn{1}{c}{ Materi } \\
\hline \multirow{2}{*}{ Kamis, 25 Maret 2021 } & Pembukaan \\
\cline { 2 - 2 } & Konsep dan Definisi Internet Sehat \\
\cline { 2 - 2 } Jum'at, 26 Maret 2021 & Uejahatan di dalam dunia Internet \\
\cline { 2 - 2 } & Etika dalam Dunia Maya \\
\hline \multirow{2}{*}{ Sabtu, 27 Maret 2021 } & Tips dan Trik Mengawasi anak didik dalam dunia Internet \\
\cline { 2 - 2 } & Evaluasi \\
\cline { 2 - 2 } & Penutupan \\
\hline
\end{tabular}

Pelaksanaan kegiatan ini diisi dengan penyampaian materi oleh tim pelaksana pengabdian sesuai dengan jadwal yang telah dijelaskan pada tabel 1. Tahapan selanjutnya yaitu pembagian selebaran terkait materi pelaksanaan pengabdian berinternet sehat beserta angket dari tim pengabdian untuk memperoleh hasil evaluasi secara deskriptif terkait dampak dari sosialisasi yang telah dilaksanakan. 


\section{ADMA}

Gurnal Pengabdian dan Pemberdayaan Masyarakat
Tahun 2021, Vol.2, No.1, pp.35-44

Doi: 10.30812/adma.v2i1.1197

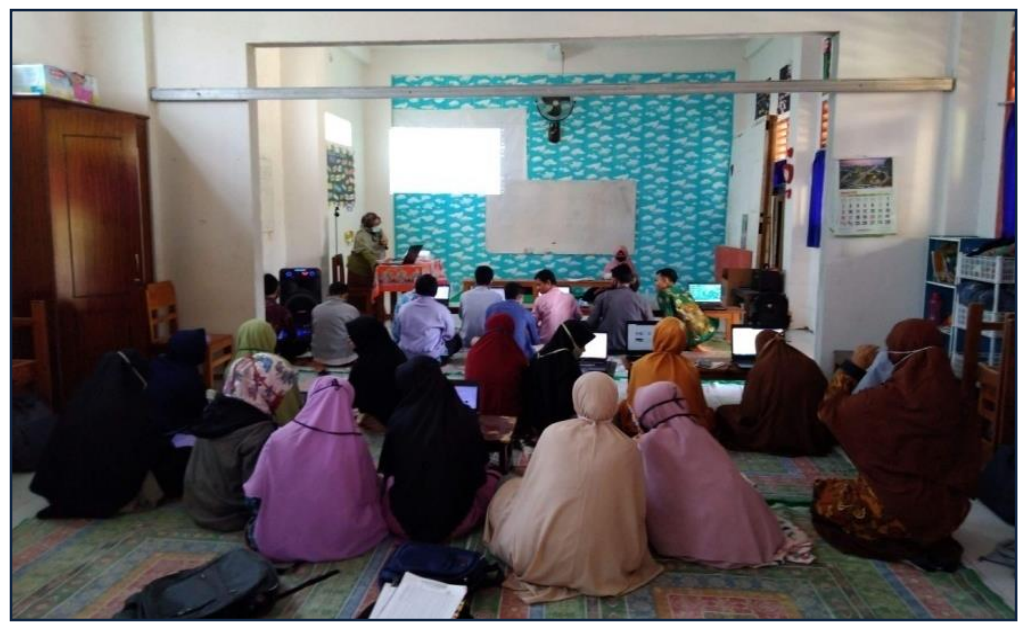

Gambar 3. Pembukaan kegiatan pengabdian sehat berinternet untuk ustadz dan ustadzah di SD IT Ulul Albab.

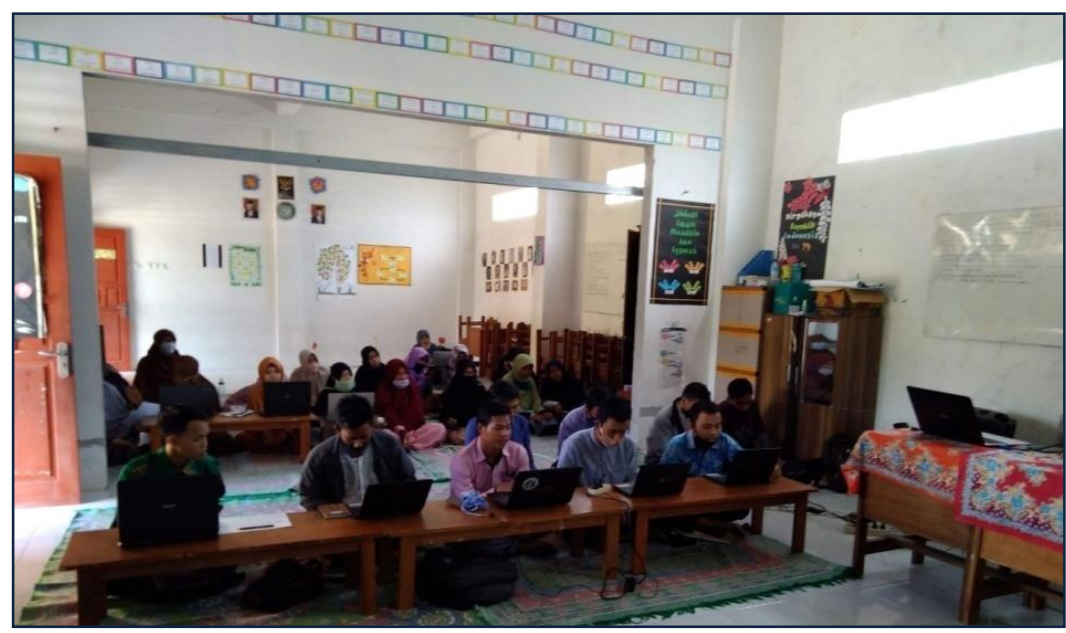

Gambar 4. Tampilan ustadz dan ustadzah SD IT Ulul Albab dalam pengabdian sehat berinternet.

Para ustadz dan ustadzah selama pelaksanaan sosialisasi banyak melontarkan pertanyaan maupun masukan terkait materi berinternet sehat yang disampaikan oleh tim, baik itu yang berhubungan dengan teknologi maupun dampak penggunakan teknologi bagi anak-anak dimasa pandemi saat ini. Masukan-masukan yang disampaikan pun bervariatif, seperti pelaksanaan sosialisasi agar dapat dilakukan dilakukan melalui zoom, dilaksanakan secara berkala, hingga pendampingan dalam meninjau penggunaan teknologi untuk anakanak SD IT Ulul Albab secara langsung. 


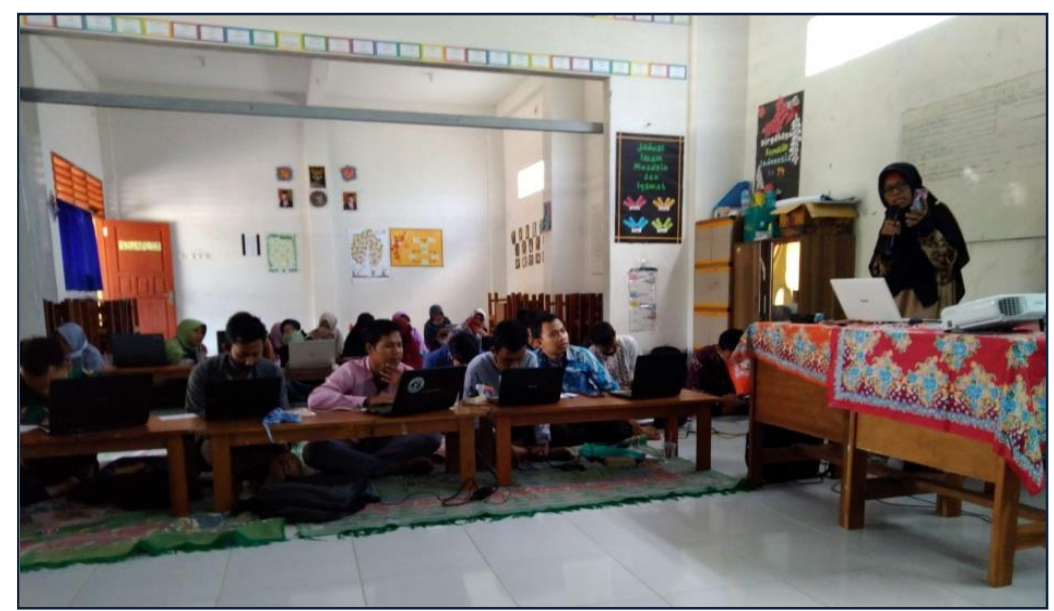

Gambar 5. Sesi sharing penyampaian mata pelajaran dengan siswa siswi SD IT Ulul Albab yang dilakukan selama pembelajaran secara daring

Kegiatan penyampaian materi dilaksanakan dengan menggunakan proyektor. Kegiatan dilaksanakan dalam waktu 30 jam pelajaran dalam jangka waktu 3 hari pelaksanaan. Materi yang disampaikan sesuai dengan gambar 2 terkait tampilan materi. Materi-materi disampaikan I dilakukan evaluasi terhadap kegiatan sosialisasi internet sehat. Evaluasi dilaksanakan dengan melaksanakan survey kepuasan pelaksanaan penelitian dengan bentuk kuesioner yang terdiri atas pertanyaan pada tabel 2. Bagitu pula hasil evaluasi dapat dilihat pada tabel 2 .

Tabel 2. Daftar pertanyaan dan jumlah responden pertanyaan

\begin{tabular}{c|l|c|c|c}
\hline \multirow{2}{*}{ No. } & \multicolumn{1}{|c|}{ Pertanyaan } & \multicolumn{3}{c}{ Jawaban } \\
\cline { 3 - 5 } & \multicolumn{1}{|c}{$\begin{array}{c}\text { Sangat } \\
\text { Setuju }\end{array}$} & Setuju & $\begin{array}{c}\text { Tidak } \\
\text { Setuju }\end{array}$ \\
\hline 1 & $\begin{array}{l}\text { Apakah materi kegiatan ini merupakan hal } \\
\text { baru bagi anda? }\end{array}$ & $\begin{array}{c}23 \\
(82 \%)\end{array}$ & $\begin{array}{c}5 \\
(18 \%)\end{array}$ & $\begin{array}{c}0 \\
(0 \%)\end{array}$ \\
\hline 2 & Apakah acara ini bermanfaat bagi anda? & $\begin{array}{c}20 \\
(71 \%)\end{array}$ & $\begin{array}{c}8 \\
(29 \%)\end{array}$ & $\begin{array}{c}0 \\
(0 \%)\end{array}$ \\
\hline 3 & $\begin{array}{l}\text { Apakah acara ini menambah wawasan anda } \\
\text { terkait internet sehat? }\end{array}$ & $\begin{array}{c}27 \\
(96 \%)\end{array}$ & $\begin{array}{c}1 \\
(3,5 \%)\end{array}$ & $\begin{array}{c}0 \\
(0 \%)\end{array}$ \\
\hline 4 & $\begin{array}{l}\text { Apakah anda setuju bahwa pamong didik/ } \\
\text { guru/ ustadz-ustadzah penting diberikan } \\
\text { pemahaman dan pelatihan terkait dengan } \\
\text { internet sehat? }\end{array}$ & $\begin{array}{c}28 \\
(100 \%)\end{array}$ & $\begin{array}{c}0 \\
(0 \%)\end{array}$ & $\begin{array}{c}0 \\
(0 \%)\end{array}$ \\
\hline 5 & $\begin{array}{l}\text { Menurut anda apakah anda setuju bahwa } \\
\text { anak didik penting diberikan pemahaman } \\
\text { terkait internet sehat? }\end{array}$ & $\begin{array}{c}28 \\
(100 \%)\end{array}$ & $\begin{array}{c}0 \\
(0 \%)\end{array}$ & $\begin{array}{c}0 \\
(0 \%)\end{array}$ \\
\hline
\end{tabular}



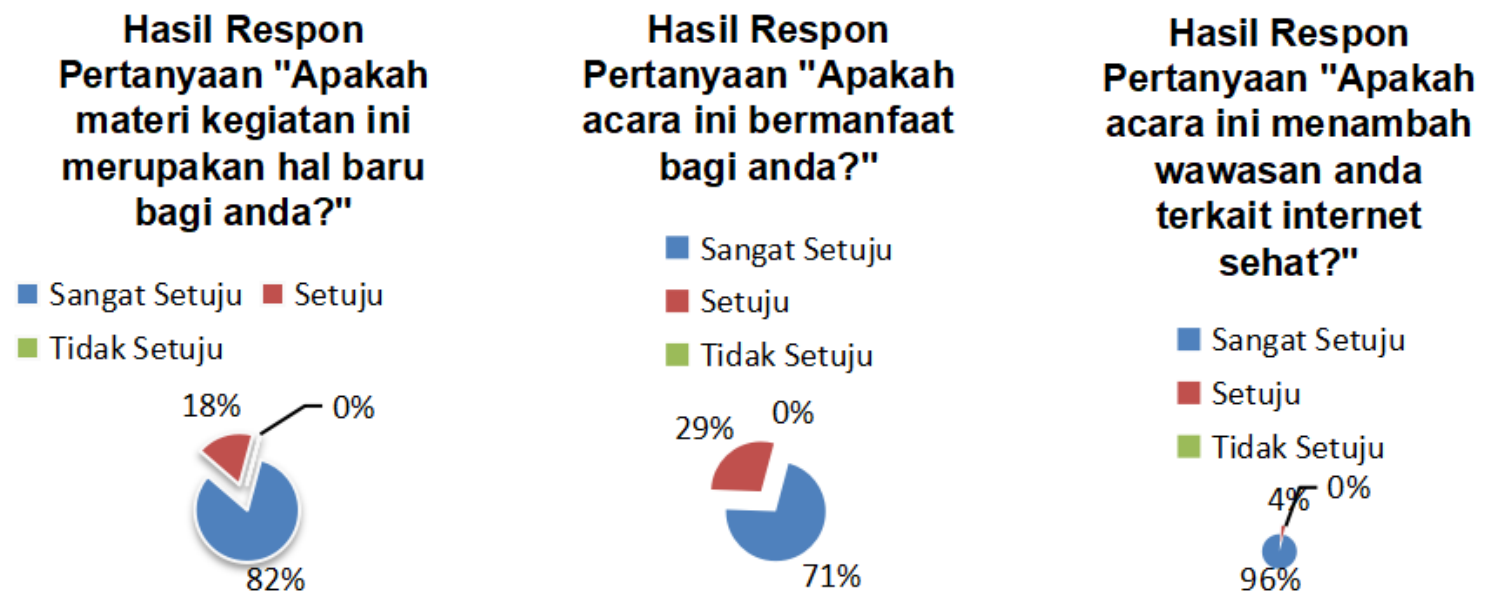

Gambar 6. Evaluasi kegiatan pengabdian sosialisasi internet sehat pada poin 1,

2 dan 3

Dari tabel 2 hasil perekapan evaluasi dapat dilihat dari jumlah peserta sebanyak 28 guru bahwa jumlah guru yang menyatakan bahwa materi kegiatan merupakan hal baru bagi mereka sebanyak 82\% (23 peserta) merasa "sangat setuju" dengan diikuti 18\% atau 5 peserta yang menyatakan "setuju" sehingga peserta yang merasa tidak setuju berjumlah $0 \%$. Selanjutnya terkait dengan peserta merasa bahwa kegiatan bermanfaat sebanyak $71 \%$ peserta merasa "sangat setuju" diikuti dengan 29\% peserta merasa "setuju" sehingga peserta yang merasa "tidak setuju" sebanyak $0 \%$. Hal tersebut dapat juga dilihat pada diagram pie yang digambarkan pada gambar 6 . Gambar 6 juga mendukung hasil tabel 2 yang menyatakan bahwa peserta yaitu guru atau ustadz/ ustadzah pada SDIT Ulul Albab merasa bahwa kegiatan yang dilakukan menambah wawasan terkait dengan internet sehat. Respon yang diberikan pada $96 \%$ pada respon "sangat setuju" lalu 4\% pada respon "setuju" sehingga respon "tidak setuju" hanya berjumlah $0 \%$.
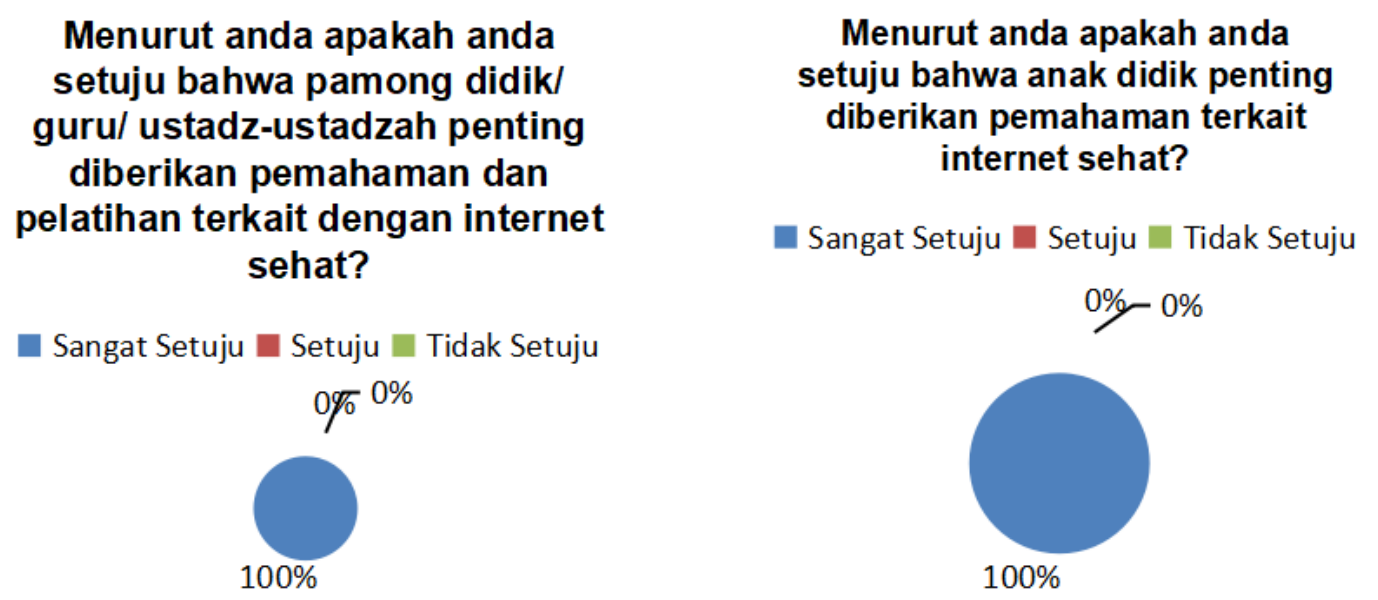

Gambar 7. Evaluasi kegiatan pengabdian sosialisasi internet sehat poin 4 dan 5 
Selain itu, hasil respondensi pada poin 4 dan 5 dari evaluasi terkait pentingnya pamong didik/guru atau asatidz untuk mendapatkan pemahaman dan pelatihan terkait dengan internet sehat adalah pada $100 \%$ respon "sangat setuju" dari kedua poin pertanyaan. Sehingga jumlah respon "setuju" dan "tidak setuju" pada poin 4 dan 5 berjumlah $0 \%$ atau tidak ada respon.

\section{Kesimpulan}

Kegiatan pengabdian ini memberikan informasi dan wawasan tambahan bagi para ustadz dan ustadzah di SD IT Ulul Albab untuk dapat menggunakan media internet secara sehat dan aman. Para ustadz dan ustadzah sangat bersemangat mengikuti kegiatan tersebut, dimana mereka dapat mengimplementasikan langsung dalam pendampingan kepada siswa siswi mereka agar lebih bijak didalam memanfaatkan media internet. Kesan positif pun ditampakkan dari beberapa peserta yang berkomitmen untuk menyisipkan beberapa materi yang tim pengabdian sampaikan untuk di teruskan ke siswa siswi didik mereka, berupa pesan sederhana maupun video yang disematkan didalam penyampaian materi pelajaran. Latar belakang dari sekolah SD IT Ulul Albab berbasis pada pendidikan agama tidak membatasi mereka untuk dapat mengikuti perkembangan trend teknologi terkini sehingga kegiatan pengabdian ini dirasa mampu memberikan nilai tambahan dalam pembelajaran sikap untuk merespon perkembangan teknologi informasi terkini.

Saran dalam kegiatan pengabdian ini adalah agar kegiatan seperti ini dapat dilaksanakan secara berkala dan menggunakan media internet seperti zoom untuk mengikuti protokol kesehatan dan memberikan wawasan tambahan bagi para ustadz, ustadzah bahkan siswa siswi SD IT Ulul Albab sehingga pemanfaatan media internet dapat dimanfaatkan secara sehat dan aman.

\section{Ucapan Terimakasih}

Ucapan terimakasih diberikan kepada para pihak yang telah membantu dalam berkontribusi dalam kesempatan dan data sehingga kegiatan Pengabdian kepada Masyarakat ini dapat berjalan dengan baik. Pihak SDIT Ulul Albab yang telah memberikan kesempatan untuk dapat berbagi ilmu dan menerapkan kepakaran dalam bidang teknologi informasi. Selain itu, terimakasih dihaturkan kepada Universitas Bumigora dan Fakultas Teknik dan Desain yang telah mendukung terlaksananya kegiatan pengabdian ini. 


\section{Daftar Pustaka}

Adnjani, M.D., \& Madrah, M. . (2014). Identitas Remaja melalui Status Sosial di Facebook.

Fitri, S., Rubiani, H., Astuti, W., \& Tasikmalaya, U. M. (n.d.). Sosialisasi berinternet sehat dan aman untuk remaja di kecamatan cihideung kota tasikmalaya jawa barat, 24-30.

Hanifah, S. (2011). Media Internet di Kalangan Siswa Sekolah Dasar (Studi) Perbandingan Antara Siswa dan Siswi Sekolah Dasar Islam Al-Azhar 5 KEMANDORAN JAKARTA).

Madrah, M. Y., Muflihin, A., Ardi, M. N., \& Makhshun, T. (2019). Pelatihan Budaya Internet Islami ( Buneti ): Internet sehat berbasis nilai-nilai islami pada kelompok PKK desa Sriwulan, Sayung Demak, 1(1), 16-31.

Winarso, D., Arribe, E., Diansyah, R., Informasi, P. S., Komputer, F. I., \& Riau, U. M. (2017). Pemanfaatan Internet Sehat Menuju, 1(1), 19-23. 